\title{
$11 \beta$-Hydroxysteroid dehydrogenase is a predominant reductase in intact rat Leydig cells
}

\author{
C M Leckie, L A M Welberg and J R SeckI
}

Molecular Endocrinology Laboratory, Molecular Medicine Centre, University of Edinburgh, Western General Hospital, Edinburgh EH4 2XU, UK

(Requests for offprints should be addressed to J R Seckl, Molecular Endocrinology Unit, Molecular Medicine Centre, University of Edinburgh, Western General Hospital, Edinburgh EH4 2XU, UK)

\begin{abstract}
$11 \beta$-Hydroxysteroid dehydrogenases (11 $\beta$-HSDs) interconvert active corticosterone and inert 11-dehydrocorticosterone. In tissue homogenates, $11 \beta$-HSD type 1 (11 $\beta$-HSD-1) exhibits both $11 \beta$-dehydrogenase (corticosterone inactivating) and $11 \beta$-reductase (corticosterone regenerating) activities, whereas $11 \beta-H S D$ type $2(11 \beta-$ HSD-2) is an exclusive dehydrogenase. In the rat testis, $11 \beta-H S D$ has been proposed to reduce glucocorticoid inhibition of testosterone production, promoting puberty and fertility. This hypothesis presupposes dehydrogenation predominates. 11 $\beta$-HSD-1 immunoreactivity has been localised to Leydig cells. However, recent studies suggest that $11 \beta$-HSD-1 is predominantly an $11 \beta$-reductase in many intact cells. We therefore examined the expression and reaction direction of $11 \beta-$ HSD isozymes in cultures of intact rat Leydig cells.

Reverse transcriptase PCR demonstrated expression of $11 \beta-H S D-1$, but not $11 \beta-H S D-2$ mRNA in rat testis. Primary cultures of intact rat Leydig cells showed pre-
\end{abstract}

dominant $11 \beta$-reductase activity, activating $50-70 \%$ of 11-dehydrocorticosterone to corticosterone over $3 \mathrm{~h}$, whereas $11 \beta$-dehydrogenation was $<5 \%$. Although both dexamethasone $(10 \mathrm{nM})$ and corticosterone $(1 \mu \mathrm{M})$ modestly inhibited LH-stimulated testosterone production by Leydig cells, inert 11-dehydrocorticosterone $(1 \mu \mathrm{M})$ had similar effects, suggesting $11 \beta$-reductase is functionally important. Carbenoxolone $\left(10^{-5} \mathrm{M}\right)$ inhibited $11 \beta-$ reduction in intact Leydig cells. However, although carbenoxolone reduced Leydig cell testosterone production, this also occurred in the absence of glucocorticoids, suggesting effects distinct from modulation of corticosteroid access to Leydig cells.

In conclusion, rat Leydig cell $11 \beta-H S D-1$ is unlikely to reduce glucocorticoid access to testicular receptors. More likely, 11ß-reductase amplifies glucocorticoid action, perhaps to maintain Leydig cell metabolic and endocrine functions.

Journal of Endocrinology (1998) 159, 233-238

\section{Introduction}

$11 \beta$-Hydroxysteroid dehydrogenase (11 $\beta$-HSD) catalyses the interconversion of active glucocorticoids (cortisol, corticosterone) and inert 11-keto forms (cortisone, 11dehydrocorticosterone), thus determining glucocorticoid access to intracellular receptors (Monder \& White 1993). Two isozymes have been identified, the products of distinct genes (Seckl 1993, White et al. 1997). 11ß-HSDtype $2(11 \beta-H S D-2)$ is a high affinity, NAD-dependent, exclusive dehydrogenase, largely confined to aldosterone target tissues and the placenta (Albiston et al. 1994, Brown et al. 1996). 11ß-HSD-2 excludes glucocorticoids from intrinsically non-selective mineralocorticoid receptors in the distal nephron and null mutations of the $11 \beta-\mathrm{HSD}-2$ gene are responsible for the clinical features of the syndrome of apparent mineralocorticoid excess (Mune et al. 1995, Stewart et al. 1996, White et al. 1997).

In contrast, considerable debate persists over the possible role of $11 \beta-H S D$ type 1 (11ß-HSD-1). This lower affinity isozyme was first isolated and cloned from rat liver (Lakshmi \& Monder 1988, Agarwal et al. 1989) and is widely expressed, with highest activity in liver, kidney, lung and testis, at least in the rat (Monder \& White 1993). So prominent was expression of $11 \beta-H S D-1$ mRNA in rat testis that a testicular library was used to isolate the human cDNA (Tannin et al. 1991). Recent studies have suggested that rat testicular $11 \beta-H S D-1$ is induced around puberty in the Leydig cell (Neumann et al. 1992), spawning the notion that it acts as an $11 \beta$-dehydrogenase, reducing inhibition of testosterone production by glucocorticoids (Phillips et al. 1989). This view was supported by the effects of enzyme inhibitors, which potentiate the otherwise modest inhibition of testosterone production by corticosterone (Monder et al. 1994a). In rat models of social and sexual dominance-subordinacy, the correlations of testicular $11 \beta-\mathrm{HSD}$ activity, inversely with corticosterone and directly with testosterone, further supported the hypothesised role of testicular $11 \beta$ HSD-1 as a 'gating-mechanism' to reduce glucocorticoid 
inhibition of testosterone production (Monder et al. 1994b).

However, we and others have recently shown that, whereas $11 \beta-H S D-1$ is bidirectional in homogenates and organelle preparations, $11 \beta$-reduction (regeneration of active corticosterone from inert 11-dehydrocorticosterone) often predominates in intact cells. $11 \beta$ Reductase predominance is seen in most transfected cells (Duperrex et al. 1993, Low et al. 1994) and in primary cultures of rat hepatocytes (Jamieson et al. 1995), lung cells (Hundertmark et al. 1995), neurons (Rajan et al. 1996), vascular smooth muscle cells (Brem et al. 1995) and human adipose cells (Bujalska et al. 1997). Moreover, 11 $\beta-H S D-1$ reductase appears functionally important, since it amplifies glucocorticoid action via glucocorticoid receptors (GR) in transfected cells (Low et al. 1994) and primary cultures (Hundertmark et al. 1995, Rajan et al. 1996). This amplification of glucocorticoid action would not conform with the proposed testicular 'barrier' role for $11 \beta-H S D$. The present study therefore re-examined rat testicular $11 \beta-\mathrm{HSD}$, to determine the isozymes present and the reaction direction in intact cells.

\section{Materials and Methods}

All sterile cell culture disposable plastic ware was obtained from Costar UK Ltd (High Wycombe, Bucks, UK), and liquid cell culture products from Gibco BRL (Paisley, UK). $\left[1,2,6,7-{ }^{3} \mathrm{H}\right]$ Corticosterone $\left(\left[{ }^{3} \mathrm{H}\right]\right.$ corticosterone $)$ was obtained from Amersham International (Aylesbury, Bucks, UK). The tritiated metabolite of $\left[{ }^{3} \mathrm{H}\right]$ corticosterone, $\left[1,2,6,7-{ }^{3} \mathrm{H}\right] 11$-dehydrocorticosterone $\left(\left[{ }^{3} \mathrm{H}\right] 11\right.$-dehydrocorticosterone) was prepared using human placental extract as described previously (Leckie et al. 1995).

\section{PCR}

Total RNA was isolated from rat kidney, liver and testes (RNeasy Total RNA Kit, Qiagen, Surrey, UK) and $1 \mu \mathrm{g}$ was reverse transcribed (Reverse Transcription System, Promega, Southampton, Hants, UK). The cDNA was denatured at $96^{\circ} \mathrm{C}$ for $15 \mathrm{~min}$ and subjected to 30 cycles of PCR $\left(96{ }^{\circ} \mathrm{C}\right.$ for $30 \mathrm{~s}, 55^{\circ} \mathrm{C}$ for $45 \mathrm{~s}$ and $72{ }^{\circ} \mathrm{C}$ for $90 \mathrm{~s}$, plus a final elongation step at $72{ }^{\circ} \mathrm{C}$ for $10 \mathrm{~min}$ ) with primers designed to the rat $11 \beta-H S D-1$ sequence (forward 5'-AAAGCTTGTCAC(AT)GGGGCCAGCAAA, reverse 5'-AGGATCCA(AG)AGCAAACTTGCTTGCA) and the rat 11 $\beta$-HSD-2 sequence (forward 5'-TGCTGCA GATGGACCTGACCAA， reverse 5'-TAGTAGTGG ATGAAGTACATGAGC).

\section{Leydig cell isolation}

The testes were removed from four adult male Han-Wistar rats $(250 \mathrm{~g})$ and placed in warmed Medium
199 containing Hanks' salts (Gibco) supplemented with $0.5 \mathrm{mg} / \mathrm{ml} \mathrm{BSA}$. Testes were decapsulated, trimmed of blood vessels and placed in pairs in $7 \mathrm{ml}$ Medium 199 containing Hanks' salts supplemented with $20 \mathrm{mM}$ Hepes buffer, $0.5 \mathrm{mg} / \mathrm{ml}$ collagenase (Worthington Lorne Laboratories, Twyford, UK), $0 \cdot 1 \%$ soybean trypsin inhibitor (Sigma Chemical Co., Poole, Dorset, UK) and $1.5 \mathrm{mg} / \mathrm{ml}$ $\mathrm{BSA}$, and placed in a shaking waterbath at $37^{\circ} \mathrm{C}$ for 40-50 min. The dissociated cells were diluted in Medium 199 containing Hanks' salts and $0.5 \mathrm{mg} / \mathrm{ml} \mathrm{BSA}$ and the seminiferous tubules were allowed to settle before filtering the supernatant through $60 \mu \mathrm{m}$ nylon gauze. The resulting cell suspension was centrifuged at $160 \mathrm{~g}$ for $10 \mathrm{~min}$ at room temperature and resuspended in $10 \mathrm{ml}$ Medium 199 containing Hanks' salts and $0.5 \mathrm{mg} / \mathrm{ml} \mathrm{BSA}$. The crude interstitial preparation was applied to a Percoll gradient consisting of five $10 \mathrm{ml}$ layers of Percoll with densities of $1 \cdot 09,1 \cdot 07,1 \cdot 05,1.03$ and $1.00 \mathrm{~g} / \mathrm{ml}$ (formed by mixing isotonic Percoll (Percoll diluted 9:1 with $10 \times$ Medium 199 containing Hanks' salts) with Medium 199 containing Hanks' salts). Five millilitres of cells were added to each of two Percoll gradients and centrifuged at $500 \mathrm{~g}$ for $24 \mathrm{~min}$ at room temperature. Cells were collected from the $1 \cdot 05 / 1 \cdot 07 \mathrm{~g} / \mathrm{ml}$ interface, diluted in Medium 199 containing Hanks' salts and $0.5 \mathrm{mg} / \mathrm{ml} \mathrm{BSA}$ and centrifuged at $200 \mathrm{~g}$ for $10 \mathrm{~min}$ at room temperature. The cells were counted, diluted to 250000 cells $/ \mathrm{ml}$ and plated on 24well plates in a volume of $1 \mathrm{ml}$ in Medium 199 containing

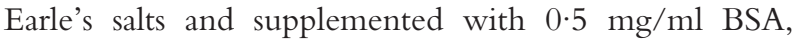
$2 \mathrm{mM}$ L-glutamine, $100 \mathrm{IU} / \mathrm{ml}$ penicillin and $100 \mu \mathrm{g} / \mathrm{ml}$ streptomycin.

The proportion of Leydig cells present in the culture was determined by staining for $3 \beta$-hydroxysteroid dehydrogenase (Payne et al. 1980). Cells were incubated overnight at $34^{\circ} \mathrm{C}$ and the medium removed and replaced with a solution prepared by mixing $1 \mathrm{mg}$ nitro-blue tetrazolium dissolved in $0.6 \mathrm{ml} 1 \mathrm{mg} / \mathrm{ml} 5 \beta$-androston$3 \beta$-ol-17-one in dimethylsulphoxide with $10 \mathrm{mg} \beta-\mathrm{NAD}$ in $9.5 \mathrm{ml}$ Dulbecco's PBS. The cells were returned to the incubator for several hours, the solution was removed and the cells were fixed in 10\% formalin in Dulbecco's PBS. The proportion of stained cells was typically $>90 \%$.

\section{$11 \beta$-HSD assay}

To assay $11 \beta-H S D$ in intact Leydig cells, the cells were incubated for $1,2,5$ or 6 days at $34^{\circ} \mathrm{C}$ and the medium removed and replaced with medium containing $25 \mathrm{nM}$ corticosterone or 11-dehydrocorticosterone with $2 \mathrm{nM}$ $\left[{ }^{3} \mathrm{H}\right]$ corticosterone or $\left[{ }^{3} \mathrm{H}\right] 11$-dehydrocorticosterone respectively as tracer. Two hundred microlitres medium were removed at 2, 3 or $6 \mathrm{~h}$, tritiated steroids extracted in $1 \mathrm{ml}$ ethyl acetate, the upper organic phase removed, evaporated under air and the steroids resuspended in $100 \mu \mathrm{l}$ ethanol containing $2.5 \mathrm{mg} / \mathrm{ml}$ each of corticosterone and 11-dehydrocorticosterone. Steroids were 
separated on TLC plates (Merck, Hoddesdon, Herts, UK) in chloroform:95\% ethanol (92:8); bands were visualised under UV light and scraped into scintillation vials containing $1 \mathrm{ml}$ liquid scintillant (Cocktail T, BDH, Poole, Dorset, UK), as previously described (Rajan et al. 1996). Steroid conversion was calculated from the radioactivity in each fraction expressed as [product]/[substrate+product]. Recovery of radioactivity was $>98 \%$ and no significant bands of radioactivity were found on the TLC plates outside the recovery areas of corticosterone and 11dehydrocorticosterone.

\section{Testosterone assay}

Cells were cultured in medium containing $10 \mathrm{nM}$ dexamethasone, $1 \mu \mathrm{M}$ corticosterone or 11-dehydrocorticosterone in the presence and absence of $10 \mu \mathrm{M}$ carbenoxolone overnight. The medium was removed after $18 \mathrm{~h}$ and replaced with medium containing the appropriate steroids, with or without carbenoxolone, supplemented with $100 \mathrm{ng} / \mathrm{ml}$ ovine luteinising hormone (LH). The medium was removed after $6 \mathrm{~h}$ and frozen for analysis of testosterone by RIA (Webb et al. 1985).

\section{Results}

Reverse transcription PCR (RT-PCR) amplified 11 $\beta$ HSD-1 transcripts of the anticipated size from RNA derived from rat liver, kidney and testis. In contrast, $11 \beta$-HSD-2 transcripts were not detected in testis, although a strong band of the predicted size was amplified from kidney (Fig. 1) and a weaker band from liver.

Medium containing $25 \mathrm{nM}$ corticosterone or 11dehydrocorticosterone was added to the cultured Leydig cells after 1, 2, 5 and 6 days of culture. After 3 h, $200 \mu l$ medium were removed for measurement of steroid conversion on each day of measurement. Over this time in culture, 11 $\beta$-dehydrogenase activity (corticosterone to 11 -dehydrocorticosterone conversion) remained below $5 \%$ (Fig. 2). In contrast, $11 \beta$-reductase was clearly detected with $50-70 \%$ of 11 -dehydrocorticosterone metabolised to corticosterone over the $3 \mathrm{~h}$ incubation period on all days of assessment. These data suggest that in intact Leydig cells $11 \beta$-HSD activity is primarily in the $11 \beta$-reductase direction and that this activity is maintained over at least a week in culture. Carbenoxolone pretreatment of intact Leydig cells in culture inhibited $11 \beta$-reductase activity with an $\mathrm{ED}_{50}$ of $\sim 5 \times 10^{-6} \mathrm{M}$ (Fig. 3). The small amount of dehydrogenase activity present was also inhibited by carbenoxolone, and this occurred at a lower concentration of carbenoxolone $\left(\mathrm{ED}_{50}\right.$ of $\left.\sim 5 \times 10^{-7} \mathrm{M}\right)$. An alternative $11 \beta-H S D$ inhibitor, glycyrrhetinic acid, also inhibited $11 \beta-H S D$ activity in intact Leydig cells with an $\mathrm{ED}_{50}$ of $\sim 10^{-6} \mathrm{M}$.

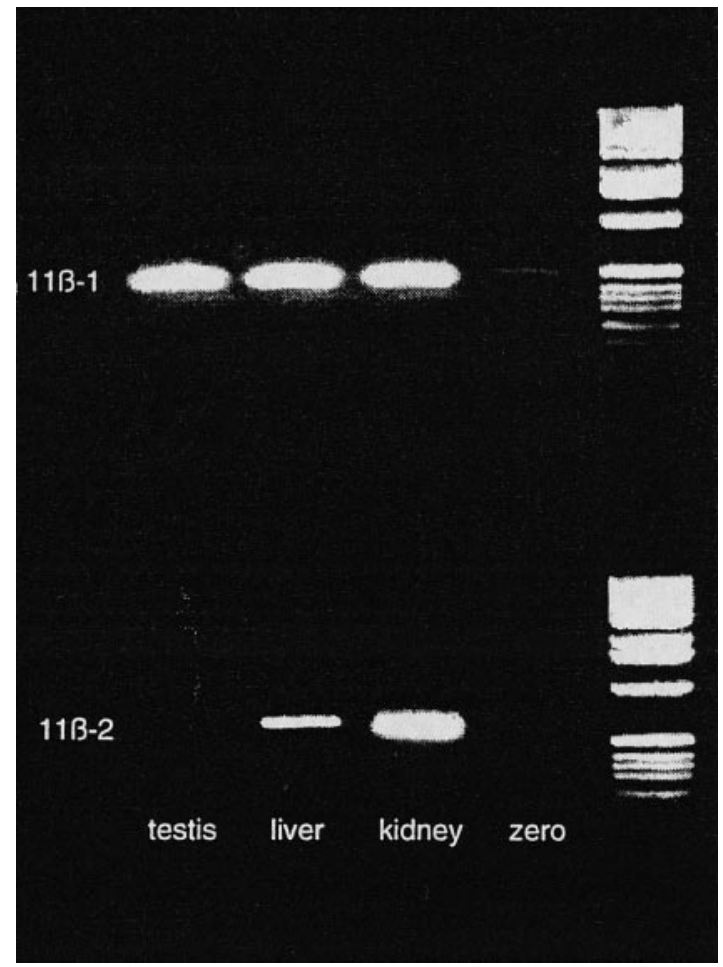

Figure 1 Expression of $11 \beta-H S D-1$, but not $11 \beta-H S D-2$, transcripts in rat testis following RT-PCR. Note the presence of $11 \beta$-HSD-1 mRNA in testis, liver and kidney, whereas $11 \beta$-HSD-2 mRNA is detected in the kidney (positive control), but not in the testis (weak expression of $11 \beta-$ HSD-2 transcripts in liver may reflect the documented expression in biliary ducts).

LH $(100 \mathrm{ng} / \mathrm{ml})$ stimulated testosterone production from cultured Leydig cells. This stimulation was inhibited by pretreatment of the Leydig cells with $10 \mathrm{nM}$

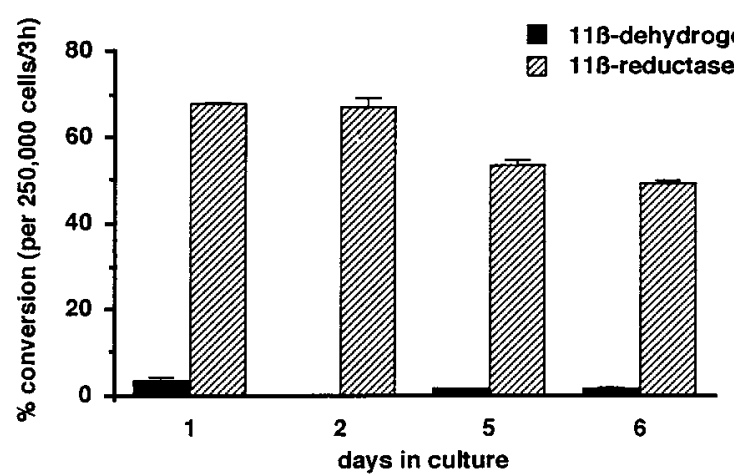

Figure $211 \beta$-HSD activity in both $11 \beta$-dehydrogenase and $11 \beta$-reductase directions in intact rat Leydig cells in primary culture for periods of 1, 2, 5 and 6 days. Enzyme activity was assessed with addition of $\left[{ }^{3} \mathrm{H}\right]$ corticosterone and $\left[{ }^{3} \mathrm{H}\right] 11$-dehydrocorticosterone respectively, and estimation of the production of steroid product per 250000 cells over $3 \mathrm{~h}$. Note the marked predominance of $11 \beta$-reductase throughout the period of culture. 


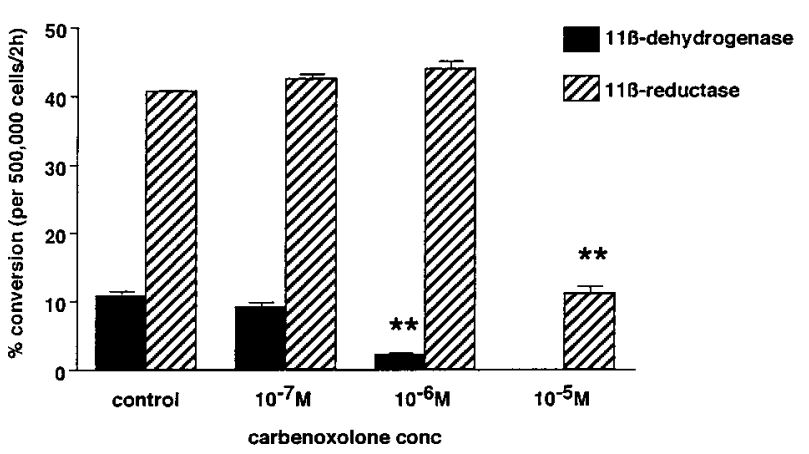

Figure 3 Effects of carbenoxolone upon $11 \beta$-reductase and $11 \beta$-dehydrogenase in rat Leydig cells in primary culture for 6 days. Enzyme activity was assessed with addition of $\left[{ }^{3} \mathrm{H}\right]$ corticosterone and $\left[{ }^{3} \mathrm{H}\right] 11$-dehydrocorticosterone respectively, with estimation of the production of steroid product per 500000 cells over 2 h. ${ }^{*} P<0.01$ compared with control.

dexamethasone, $1 \mu \mathrm{M}$ corticosterone and $1 \mu \mathrm{M} 11$ dehydrocorticosterone (Fig. 4). Ten micromolar carbenoxolone, a concentration required to inhibit appreciably $11 \beta$-reductase activity, itself inhibited testosterone production from Leydig cells in culture in the absence of any added steroid (Fig. 4); addition of glucocorticoids to carbenoxolone had no additional effect upon LHstimulated testosterone production. It was therefore clearly impossible to determine the effect of carbenoxolone on the inhibition of testosterone production by glucocorticoids.

\section{Discussion}

Sensitive RT-PCR showed $11 \beta-H S D-1$, but no $11 \beta$ HSD-2, mRNA expression in the rat testis. The data confirm previous reports of $11 \beta-\mathrm{HSD}-1 \mathrm{mRNA}$ and immunoreactivity in the rat testis (Agarwal et al. 1989, Monder \& Lakshmi 1990) and the absence of 11ß-HSD-2 transcripts in rat testicular extracts (Zhou et al. 1995). Immunocytochemical studies have suggested that $11 \beta$ HSD-1 is localised to the Leydig cell (Phillips et al. 1989), although the presence on Western blots of testicular extracts of immunoreactive species smaller than the presumed authentic $34 \mathrm{kDa} 11 \beta-\mathrm{HSD}-1$ may reflect some polyspecificity of the antisera employed (Agarwal et al. 1989, Monder \& Lakshmi 1990). Our unpublished in situ hybridisation data show high 11 $\beta-H S D-1$ mRNA expression in the interstitium, compatible with the immunolocalisation.

$11 \beta-H S D$ in intact rat Leydig cells in culture was a predominant $11 \beta$-reductase. These results conform with most previous studies of $11 \beta-H S D-1$ in intact cells (Duperrex et al. 1993, Low et al. 1994, Hundertmark et al. 1995, Jamieson et al. 1995, Rajan et al. 1996), and more recently, with the predominant reaction direction in whole organs (Jamieson et al. 1997) and in vivo

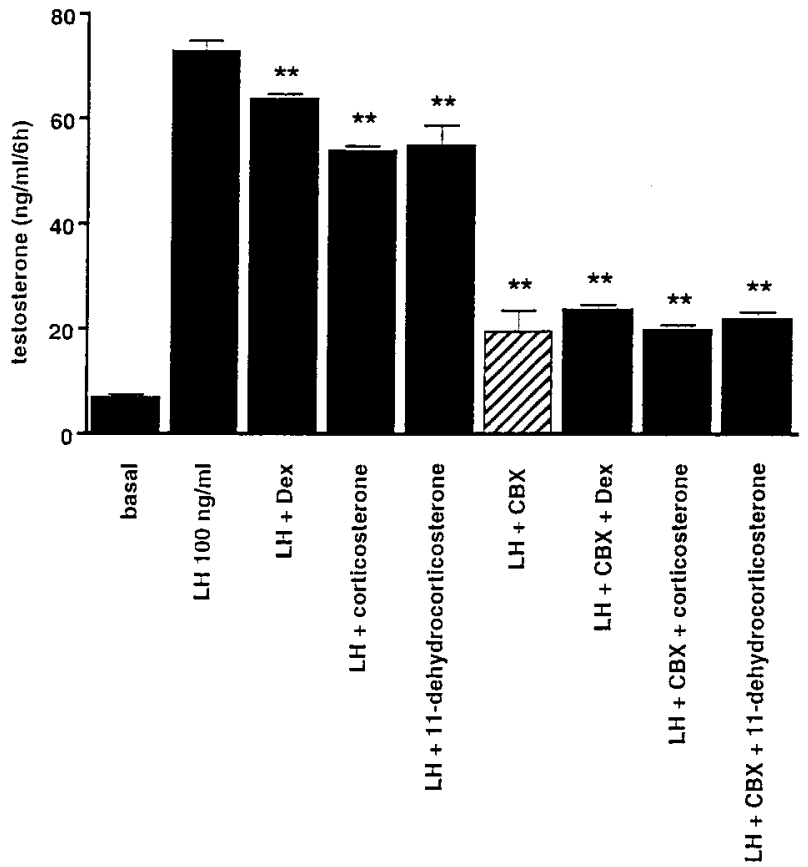

Figure 4 Effects of glucocorticoids (dexamethasone (Dex), corticosterone and 11-dehydrocorticosterone) and carbenoxolone (CBX) upon $\mathrm{LH}$-stimulated testosterone production by rat Leydig cells in primary culture. ${ }^{* *} P<0 \cdot 01$ compared with $\mathrm{LH}$ alone. Note the modest inhibition of $\mathrm{LH}$-stimulated testosterone production by dexamethasone $(10 \mathrm{nM})$ and corticosterone $(1 \mu \mathrm{M})$. Otherwise inert 11-dehydrocorticosterone $(1 \mu \mathrm{M})$ has similar effects to corticosterone, suggesting $11 \beta$-reductase activity may be functionally important. Also note the direct and more potent inhibitory effects of carbenoxolone $(10 \mu \mathrm{M})$ alone in the absence of corticosteroids (hatched bar) than glucocorticoids themselves and the lack of additional effects of corticosteroids with carbenoxolone.

(Kotelevtsev et al. 1997). However, Monder et al. (1994a) found significant $11 \beta$-dehydrogenation in rat Leydig cells, although reductase activity was not determined. More recently, Gao et al. (1997) reported bidirectional 11ßHSD activity, with predominant $11 \beta$-dehydrogenation, in rat Leydig cells. The reason for the discrepancies between these studies and our own is unclear. In the studies of Gao et al., Leydig cells were harvested from culture dishes and taken into suspension before assay of reaction direction. $11 \beta-H S D-1$ shows predominant $11 \beta$-reduction in intact cells, but is bidirectional in homogenates or even when damaged cells are present (Low et al. 1994, Jamieson et al. 1995, Rajan et al. 1996). Moreover, in homogenates $11 \beta$-dehydrogenation is apparently more stable than $11 \beta-$ reduction, so even limited cellular disruption will favour dehydrogenation, a contention supported by the detection by these authors of dehydrogenation in similarly treated hepatocytes, whereas activity in undisturbed hepatocyte cultures and in intact liver is predominantly reductive (Jamieson et al. 1995, 1997). Alternative explanations, of 
possible strain differences in Leydig cell reaction direction or the existence of novel 11 $\beta-H S D$ isozymes in Leydig cells, lack experimental support. Moreover, two further results suggest that $11 \beta-H S D-1$ functions as a reductase. First, the effects of dexamethasone and corticosterone to inhibit testosterone production by Leydig cells were similar, which does not support the notion that physiological glucocorticoid effects are modulated by $11 \beta$ dehydrogenase. Secondly, otherwise inert 11-dehydrocorticosterone was as potent as corticosterone in inhibiting the output of testosterone from Leydig cell cultures. Thus, it is probable that Leydig cell $11 \beta-\mathrm{HSD}-1$ is activating 11-dehydrocorticosterone to corticosterone, which itself reduces testosterone production.

Our data also confirm previous work (Monder et al. 1994a) and show that glucocorticoids modestly inhibit LH-stimulated testosterone production by Leydig cells (Welsh et al. 1982). If $11 \beta$-dehydrogenation reduces this action, then $11 \beta-H S D$ inhibitors should amplify the effects of corticosterone. However, carbenoxolone alone, at the minimum concentration to inhibit $11 \beta-\mathrm{HSD}-1$ in rat Leydig cells, itself markedly reduced the production of testosterone in response to $\mathrm{LH}$. This effect occurred in the absence of glucocorticoids and was of considerably greater magnitude than the action of even the potent synthetic glucocorticoid dexamethasone, which is not a substrate for 11/-HSD-1. Although the mechanism of this effect is obscure, it renders impossible the determination of whether pharmacological inhibition of Leydig cell $11 \beta$ HSD-1 has any effect upon the glucocorticoid control of testosterone production.

The function of an 11 $\beta$-reductase in rat Leydig cells is unknown. GR binding sites and immunoreactivity have been reported in Leydig cells (Neumann et al. 1992, Schultz et al. 1993). Whilst glucocorticoids suppress gonadotrophin-induced testosterone production by Leydig cells, by inhibiting transcription of steroidogenic enzymes (Welsh et al. 1982, Hales \& Payne 1989, Payne \& Sha 1991), higher doses of corticosterone may stimulate basal testosterone production (Orr \& Mann 1992). Indeed, glucocorticoids are necessary for expression of gonadotrophin receptors in Leydig cells (Engel \& Frowein 1974). Thus $11 \beta$-reductase might amplify gonadotrophin responsiveness. In addition, glucocorticoids are necessary for many constitutive metabolic processes (Miller \& Tyrrell 1995). The prominent diurnal rhythm of corticosterone may not provide sufficient ligand during the nadir, when 'free' corticosterone levels (allowing for 90-95\% binding by corticosteroid-binding globulin) are very low (Akana et al. 1992). In contrast, 11-dehydrocorticosterone levels are around $50 \mathrm{nM}$ in rat plasma (R Best and J R Seckl, unpublished data) and in humans cortisone circulates, largely unbound, at around $100 \mathrm{nM}$ (Walker et al. 1992), providing plentiful substrate for an $11 \beta$-reductase. Alternatively, glucocorticoids may not be the major substrate for testicular 11ß-HSD-1. 11-Hydroxy-androgens or 11-hydroxy-progesterones may affect rat Leydig cell testosterone production (Monder \& White 1993), though the presence of 11-hydroxy-progesterone has not been demonstrated in mammalian tissues or human urine (Morita et al. 1996). Finally, 11 $\beta-H S D$ activity and $11 \beta-H S D-1$ mRNA are absent from mouse (Rajan et al. 1995) and squirrel monkey (Moore et al. 1993) testis. These data do not suggest that $11 \beta-H S D-1$ provides any generic mammalian system to 'gate' glucocorticoid effects in the post-pubertal testes. Indeed male mice with targeted disruption of the $11 \beta-\mathrm{HSD}-1$ gene are fertile (Kotelevtsev et al. 1997).

\section{Acknowledgements}

We thank the Assay Group of the Medical Research Council's Reproductive Biology Unit, Edinburgh for testosterone radioimmunoassays. This work was supported by a Wellcome Trust Programme grant (J R S), a Wellcome Senior Clinical Research Fellowship (J R S) and a Wellcome Prize studentship (L A M W).

\section{References}

Agarwal AK, Monder C, Eckstein B \& White PC 1989 Cloning and expression of rat cDNA encoding corticosteroid 11-dehydrogenase. Journal of Biological Chemistry 264 18939-18943.

Akana SF, Scribner KA, Bradbury MJ, Strack AM, Walker CD \& Dallman MF 1992 Feedback sensitivity of the rat hypothalamopituitary-adrenal axis and its capacity to adjust to exogenous corticosterone. Endocrinology 131 585-594.

Albiston AL, Obeyesekere VR, Smith RE \& Krozowski ZS 1994 Cloning and tissue distribution of the human $11 \beta$-hydroxysteroid dehydrogenase type 2 enzyme. Molecular and Cellular Endocrinology 105 R11-R17.

Brem AS, Bina RB, King T \& Morris DJ 1995 Bidirectional activity of 11 beta-hydroxysteroid dehydrogenase in vascular smooth muscle cells. Steroids 60 406-410.

Brown RW, Kotolevtsev Y, Leckie C, Lindsay RS, Lyons V, Murad P, Mullins JJ, Chapman KE, Edwards CRW \& Seckl JR 1996 Isolation and cloning of human placental $11 \beta$-hydroxysteroid dehydrogenase-2 cDNA. Biochemical Journal 313 1007-1017.

Bujalska I, Kumar S \& Stewart PM 1997 Central obesity: 'Cushing's disease of the omentum'. Lancet 349 1210-1213.

Duperrex H, Kenouch S, Gaeggeler H-P, Seckl JR, Edwards CRW, Farman N \& Rossier BC 1993 Rat liver 11ß-hydoxysteroid dehydrogenase cDNA encodes oxoreductase activity in a mineralocorticoid-responsive toad bladder cell line. Endocrinology 132 612-619.

Engel W \& Frowein J 1974 Glucocorticoids and hCG sensitivity of rat testicular Leydig cells. Nature 251 146-148.

Gao HB, Ge RS, Lakshmi V, Marandici A \& Hardy MP 1997 Hormonal regulation of oxidative and reductive activities of 11 beta-hydroxysteroid dehydrogenase in rat Leydig cells. Endocrinology 138 156-161.

Hales DB \& Payne AH 1989 Glucocorticoid-mediated repression of P450(SCC) mRNA and de novo synthesis in cultured Leydig cells. Endocrinology 124 2099-2104.

Hundertmark S, Buhler H, Ragosch V, Dinkelborg L, Arabin B \& Weitzel HK 1995 Correlation of surfactant phosphatidylcholine 
synthesis and 11beta-hydroxysteroid dehydrogenase in the fetal lung. Endocrinology 136 2573-2578.

Jamieson PM, Chapman KE, Edwards CRW \& Seckl JR 1995 $11 \beta$-Hydroxysteroid dehydrogenase is an exclusive $11 \beta$-reductase in primary cultured rat hepatocytes: effect of physicochemical and hormonal manipulations. Endocrinology 136 4754-4761.

Jamieson PM, Walker BR, Chapman KE, Rossiter S \& Seckl JR 1997 11-Hydroxysteroid dehydrogenase type 1 is a predominant reductase in the intact perfused rat liver. Journal of Endocrinology 152 (Suppl) OC8.

Kotelevtsev Y, Holmes MC, Burchell A, Houston PM, Schmoll D, Jamieson PM, Best R, Brown R, Edwards CRW, Seckl JR \& Mullins JJ 1997 11ß-Hydroxysteroid dehydrogenase type 1 knockout mice show attenuated glucocorticoid inducible responses and resist hyperglycaemia on obesity or stress. Proceedings of the National Academy of Sciences of the USA 94 14924-14929.

Lakshmi V \& Monder C 1988 Purification and characterisation of the corticosteroid $11 \beta$-dehydrogenase component of the rat liver $11 \beta$-hydroxysteroid dehydrogenase complex. Endocrinology 123 2390-2398.

Leckie CM, Chapman KE, Edwards CRW \& Seckl JR 1995 LLC-PK 1 cells model $11 \beta$-hydroxysteroid dehydrogenase type 2 regulation of glucocorticoid access to renal mineralocorticoid receptors. Endocrinology 136 5561-5569.

Low SC, Chapman KE, Edwards CRW \& Seckl JR 1994 Liver-type $11 \beta$-hydroxysteroid dehydrogenase cDNA encodes reductase not dehydrogenase activity in intact mammalian COS-7 cells. Journal of Molecular Endocrinology 13 167-174.

Miller WL \& Tyrrell JB 1995 The adrenal cortex. In Endocrinology and Metabolism, edn 3, pp 555-711. Eds P Felig, JD Baxter \& L Frohman. New York: McGraw Hill.

Monder C \& Lakshmi V 1990 Corticosteroid 11 $\beta$-dehydrogenase of rat tissues: immunological studies. Endocrinology 126 2435-2443.

Monder C \& White PC 1993 11ß-Hydroxysteroid dehydrogenase. Vitamins and Hormones 47 187-271.

Monder C, Miroff Y, Marandici A \& Hardy MP 1994a $11 \beta$-Hydroxysteroid dehydrogenase alleviates glucocorticoidmediated inhibition of steroidogenesis in rat Leydig cells. Endocrinology 134 1199-1204.

Monder C, Sakai RR, Miroff Y, Blanchard DC \& Blanchard RJ $1994 b$ Reciprocal changes in plasma corticosterone and testosterone in stressed male rats maintained in a visible burrow system: evidence for a mediating role of testicular $11 \beta$-hydroxysteroid dehydrogenase. Endocrinology 134 1193-1198.

Moore CCD, Mellon SH, Murai J, Siiteri PK \& Miller WL 1993 Structure and function of the hepatic form of $11 \beta$-hydroxysteroid dehydrogenase in the squirrel monkey, an animal model of glucocorticoid resistance. Endocrinology 133 368-375.

Morita H, Zhou M, Foecking MF, Gomez-Sanchez EP, Cozza EN \& Gomez-Sanchez CE 1996 11ß-Hydroxysteroid dehydrogenase type 2 complementary deoxyribonucleic acid stably transfected into chinese hamster ovary cells: specific inhibition by 11alphahydroxyprogesterone. Endocrinology 137 2308-2314.

Mune T, Rogerson FM, Nikkilö H, Agarwal AK \& White PC 1995 Human hypertension caused by mutations in the kidney isozyme of 11ß-hydroxysteroid dehydrogenase. Nature Genetics 10 394-399.

Neumann A, Haider SG \& Hilscher B 1992 Temporal coincidence of the appearance of elongated spermatids and of histochemical reaction of $11 \beta$-hydroxysteroid dehydrogenase in rat Leydig cells. Andrologia 24 263-269.
Orr TE \& Mann DR 1992 Role of glucocorticoids in the stressinduced suppression of testicular steroidogenesis in adult male rats. Hormones and Behavior 26 350-363.

Payne AH \& Sha L 1991 Multiple mechanisms for regulation of 3beta-hydroxysteroid dehydrogenase/Delta5-Delta4-isomerase, 17alpha-hydroxylase/C17-20 lyase cytochrome P450, and cholesterol side-chain cleavage cytochrome P450 messenger ribonucleic acid levels in primary cultures of mouse Leydig cells. Endocrinology 129 1429-1435.

Payne AH, Downing J \& Wongi KL 1980 Luteinizing hormone receptors and testosterone synthesis in two distinct populations of Leydig cells. Endocrinology 106 1424-1429.

Phillips MD, Lakshmi V \& Monder C 1989 Corticosteroid $11 \beta$-dehydrogenase in rat testis. Endocrinology 125 209-216.

Rajan V, Chapman KE, Lyons V, Jamieson P, Mullins JJ, Edwards CRW \& Seckl JR 1995 Cloning, sequencing and tissue-distribution of mouse 11ß-hydroxysteroid dehydrogenase-1 cDNA. Journal of Steroid Biochemistry and Molecular Biology 52 141-147.

Rajan V, Edwards CRW \& Seckl JR 1996 11ß-Hydroxysteroid dehydrogenase in cultured hippocampal cells reactivates inert 11-dehydrocorticosterone, potentiating neurotoxicity. Journal of Neuroscience 16 65-70.

Schultz R, Isola J, Parvinen M, Honkaniemi J, Witdstrom AC, Gustafsson JA \& Pelto-Huitko M 1993 Localization of the glucocorticoid receptor in testis and accessory sexual organs of male rats. Molecular and Cellular Endocrinology 95 115-120.

Seckl JR 1993 11 $\beta$-Hydroxysteroid dehydrogenase isoforms and their implications for blood pressure regulation. European Journal of Clinical Investigation 23 589-601.

Stewart P, Krozowski Z, Gupta A, Milford D, Howie A, Sheppard M \& Whorwood C 1996 Hypertension in the syndrome of apparent mineralocorticoid excess due to mutation of the 11 betahydroxysteroid dehydrogenase type 2 gene. Lancet 347 88-91.

Tannin GM, Agarwal AK, Monder C, New MI \& White PC 1991 The human gene for $11 \beta$-hydroxysteroid dehydrogenase. Journal of Biological Chemistry 266 16653-16658.

Walker BR, Campbell JC, Fraser R, Stewart PM \& Edwards CRW 1992 Mineralocorticoid excess and inhibition of $11 \beta$-hydroxysteroid dehydrogenase in patients with ectopic ACTH syndrome. Clinical Endocrinology 37 483-492.

Webb R, Baxter G, McBride D, Nordblom GD \& Shaw MPK 1985 The measurement of testosterone and oestradiol-17 $\beta$ using iodinated tracers and incorporating an affinity chromatography extraction procedure. Journal of Steroid Biochemistry 23 1043-1051.

Welsh TJ, Bambino TH \& Hsueh AJW 1982 Mechanism of glucocorticoid-induced suppression of testicular androgen biosynthesis in vitro. Biology of Reproduction 27 1138-1146.

White PC, Mune T \& Agarwal AK 1997 11Beta-hydroxysteroid dehydrogenase and the syndrome of apparent mineralocorticoid excess. Endocrine Reviews 18 135-156.

Zhou M-Y, Gomez-Sanchez EP, Cox DL, Cosby D \& Gomez-Sanchez CE 1995 Cloning expression and tissue-distribution of the rat NAD-dependent $11 \beta$-hydroxysteroid dehydrogenase. Endocrinology 136 3729-3734.

Received 21 August 1997

Revised manuscript received 2 April 1998

Accepted 17 June 1998 